привлечению детей в спортивные секции, задействованы олимпийские спортивные объекты для развития молодежи. Открыты научные центры для одаренных детей. На сегодняшний день в олимпийском парке открыты бесплатные площадки для занятия велоспортом, скейтбордами. Главной задачей является привлечение молодежи к науки и спорту, для воспитания здорового, умного поколения.

В Сочи такие олимпийские объекты как «Большой» ледовый дворец, дворец «Айсберг», арена «Ледяной клуб» были отведены для развития детского хоккея, фигурного катания, игры в керлинг. Открытия центра для одаренных детей «Сириус» помогает одаренным подросткам проявлять себя в научных сферах. В феврале 2018 года на Сочинском инвестиционном форуме «Сириус» представит проект реконструкции медиацентра, рассчитанный на два-три года и предусматривающий строительство концертного зала.

\title{
Литература
}

1. Батракова С.Н. Основы профессионально-педагогического общения.Ярославль 1989

2. Лихачев Б.Т. Педагогика изд Юрайт - 2001г.

3. Реан А.А. Коломинский Я.П. Социальная педагогическая психология. СПб., 1999.

4. Саруханов Э.Р. Проблемы управления профессиональной ориентацией. - Л. 1991.

5. Формирование личности старшеклассника. -- М., 1989.

6. Хекхаузен Х. Мотивация и деятельность. -- М., 1986.

\section{ОСОБЕННОСТИ ИН- И АУТГРУПП КАК ОБЪЕКТ ВОЗДЕЙСТВИЯ РУКОВОДИТЕЛЯ}

Глушак В.А.

В руководстве как отдельном аспекте управленческой деятельности наиболее важный объект воздействия - коллектив.

Руководство группой - важный фактор достижения максимальных результатов совместного труда и эффективности использования человеческих ресурсов.

Поскольку в управлении необходимо организовать, активизировать и поддерживать деятельность отдельного работника и группы, руководителю с позиций психологии управления рекомендовано оказывать воздействие на группы с учетом групповых феноменов.

Каждый раз, когда руководитель дает указания группе исполнителей, то он предполагает, что его указание полностью отразится в сознании людей и сразу же последуют желаемые действия. Однако, так бывает не всегда. Даже при осознании человеком своих задач и функций может не последовать ожидаемых действий при включении человека при этом в определённую группу.

Для того чтобы оказывать воздействие на подчиненных и побуждать их к необходимым действиям, руководителю необходимо иметь возможность держать под своим контролем что-либо, имеющее значение для исполнителя. 
Основной побудительной силой с точки зрения психологии являются потребности человека, то есть руководитель при оказании воздействия должен апеллировать к активным потребностям подчинённых.

Вхождение в группу - фундаментальная потребность социализации, поэтому изучение движения человека в группу или из группы в теории и практике управления приближает эту проблему к фундаментальным.

Чувство и осознание принадлежности к группе порождает такой феномен как «ин-группы», а ощущение соперничества, оппозиции общности других людей ведет к появлению «аут-групп».

Термины ввел американский социолог У.Г. Самнер (1906), установивший закон этноцентризма: степень враждебности, направленной в сторону аутгруппы, пропорциональна степени сплоченности ин-группы.

Итак, чья-то «ин-группа» может быть для кого-то «аут-группой», и наоборот. Членов «ин-группы» человек расценивает как «мы», членов аутгрупп - как «чужие».

Члены «аут-группы» могут обладать теми же чертами, что и члены «ингруппы», однако при сравнении акцент будет сделан именно на тех чертах, которые отличают чужих от своих. Попадая в новую обстановку, человек стремится выяснить, кто здесь «свой» и налаживает отношения именно с ним.

Ин-групповая идентификация каждой личности существенно сказывается на поведении. От соратников по группе ожидают участия, признания, помощи. Ожидаемое поведение представителя «аут-группы» зависит от вида этой группы, опыта прошлых отношений с ней самого индивида и его «ин-группы».

Ин-группы отличаются сплоченностью, стереотипизацией и этноцентризмом. А так же в таких группах зафиксирован ингрупповой фаворитизм, когда «...все позитивные эмоции - такие, как восхищение, симпатия и доверие - зарезервированы для ин-группы» (Brewer, 1999).

В аут-группах исследователи обнаружили явление аут-групповой однородности, когда представители другой группы воспринимаются как «они» и «все на одно лицо» (Linville, 1998).

Итак, в современном обществе в целом и конкретно в организации человек принадлежит одновременно ко многим группам, поэтому большое число ингрупповых и аут-групповых связей пересекается.

Тем не менее, рассмотренные социально-психологические феномены данных групп, позволяют сформулировать ряд рекомендаций для руководителей с целью выделения объекта психологического воздействия на группу.

Так, например, при воздействии на аут-группы необходимо учитывать, что представителей других коллективов они слабо дифференцируют не только внешне, но и по личностным качествам. То есть другие группы воспринимаются как одинаковые, нет персонализации оппонентов, учета из личностных особенностей.

При руководстве ин-группой, конечно, руководитель вправе опираться на феномен групповой сплоченности, проявляющийся я «чувстве локтя», взаимной поддержке, уважении друг друга членами коллектива. Так же 
положительную роль в оказании управленческого воздействия на ин-группу может оказать ингрупповой фаворитизм, при котором вся информация в такой группе щедро сопровождается положительными эмоциями и феномен стереотипизации, когда восприятия и суждения строятся на устойчивых клише и ярлыках. Как именно это будет использоваться руководителем - не является предметом данной статьи, однако, понятно, что на базе описанных выше закономерностей, можно успешно формировать нужное впечатление или мнение у членом ин-группы.

Кроме названного выше, руководителю следует учитывать, что в ингруппе может сложиться предвзятое мнение о представителях других групп на основе феномена этноцентризма, который, как известно, искажает межличностное восприятие.

То есть аут- ингрупповая специфика может служить существенным фактором эффективного руководства группой, особенно при возникновении острых управленческих задач, противоречий между различными группами, дефицита времени и других организационных или производственных ситуаций.

\section{Литература}

1. Руководство малой группой. Р.Л. Кричевский, Е.М. Дубовская / Кричевский Р.Л., Дубовская Е.М. Психология малой группы. М.: Изд-во Моск. ун-та, 1991.

2. Социальная психология Почебут Л. Г., Мейжис И.А. - СПб, Изд-во «Питер», 2010 - 672c.

3. Социология: Курс лекций (Под ред. Михайлова В.А.) - Ульяновск: УлГТУ, 2004.- 207 c.

\section{РУКОВОДСТВО ИН-АУТ-ГРУППАМИ И ЛИЧНОСТЬ РУКОВОДИТЕЛЯ}

Глушак В.А.

Стать прекрасным руководителем может каждый, но не каждый знает, какими качествами должен обладать руководитель. Если потребность в руководящей деятельности высока, то возрастает актуальность знаний об отличительных чертах характера эффективных руководителей.

На практике бывает, что даже самый первоклассный руководитель не знает, как разрешить конфликт между «своими» и «чужими» группами, или замотивировать их на общее дело, повысить производительность труда и др.

Итак, что это за группы и как с ними работать руководителю за счет собственных ресурсов личности?

Руководитель - это не только должность, это, желательно еще и лидер, который мотивирует свою команду - подчиненных на хорошую и активную работу, что очень важно в любой деятельности [1].

Не существует каких-то шаблонных требований к руководителю, в каждой сфере деятельности, в каждом подразделении существуют свои требования, поэтому, вопрос о нужном проявлении и верном формировании качеств у человека как руководителя, его деятельности значимо и актуально на 